\title{
The Effectiveness of Group Guidance with Modelling in Increasing The Maturity of Career Choice
}

\author{
Sisri Wahyuni ${ }^{1}$, A. Muri Yusuf ${ }^{2}$, Z. Mawardi Efendi ${ }^{3}$ \\ 1,2,3 Universitas Negeri Padang, Padang, Indonesia \\ *Corresponding author, e-mail: sisriwahyuni@yahoo.co.id
}

\begin{abstract}
The maturity of the career choice direction becomes a central idea in the career development of the students. There are still many students who are less thorough in understanding career information. Therefore, the purpose of this study is to look at the effectiveness of group counseling services with modelling in improving student career choices. The research used quasi experimental approach through the design of non equivalent control group. Research subjects seven students experimental group and seven students control group. This research used career maturity choice with reliability 0.86 . Then the data were analyzed using Wilcoxon Signed Ranks Test and Kolmogorov Smirnov 2 Independent Samples and Normalized Gain Scores. The result shows that group counseling service with modelling effective for increase the career maturity choices
\end{abstract}

Keywords: The Maturity Of The Career Choice, Modelling Approach and Group Guidance.

How to Cite: Wahyuni, S., Yusuf, A. M., \& Efendi, Z. M. (2017). The Effectiveness of Group Guidance with Modelling in Increasing The Maturity of Career Choice. International Journal of Research in Counseling and Education, 1(1), 37-46. https://doi.org/10.24036/0011za0002

This is an open access article distributed under the Creative Commons 4.0 Attribution License, which permits unrestricted use, distribution, and reproduction in any medium, provided the original work is properly cited. C2017 by author and Universitas Negeri Padang.

\section{Introduction}

It is useful for the students in educational institutions to prepare themselves and participate actively in the world of work appropriate with their potential and hold a position that is meaningful for themselves and society. The success of students in his career in the future is closely related to how to choose a suitable place to develop the potential owned. Students need to be directed to understand their own environment and decision-making process, the more steady prepare to make a decision based on the understanding of self, living situation and guided by the relevant information processing and able to plan a career well.

Students need to plan well in their future careers and need to develop them optimally to improve career maturity. The long process of career development iAn career maturity according to Super and Bowlsbey (1979) is a development throughout the span of human life from birth to end of human life in this world. The development of individual careers throughout the life span is integrated in every role, setting and event in life that is influenced by many factors (Gibson, 2015). Meanwhile Dillard (1985) says that career maturity is an individual attitude in career decision making that is expressed by the level of consistency of career choice in a certain period.

Career maturity is the ability of individuals in the pattern of actualization themselvesappropriate with the ability to support future career direction. Super (in Winkel, 2004) defines career maturity as an individual's success to complete typical career development tasks for a particular stage of development. Super (in Savickas, 2001) also explains that individuals are said to be mature or ready to make career decisions if the knowledge they have for making career decisions is supported by appropriate information on work based on the exploration that has been done.

Based on the above opinion it is understood that the maturity of a student's career will differ depending on the stage of student career development itself. Maturity can identify appropriate job 
opportunities and levels and also consider needs, interests, competency capacities, and personal values. Therefore, the concept of career maturity is normative, it means that there must be a match between individual career development with the expected development. The direction of career choice is defined as the success of a person completing typical career development tasks at a certain stage of development.

Looking at the importance of the maturity of career choice in life, the students need to be helped to understand well the alternatives of the majors, in accordance with their potential, so that students can choose and plan careers appropriately. The maturity of career choice direction includes knowledge of self, knowledge of work, ability to choose a job, and the ability to plan the steps towards anexpected career. The ability must be nurtured through efforts to accompany the career development of students to be able to understand the condition of the self well, the environment and decision-making process and steadier prepare in terms of knowledge, skills, attitudes and values, required in career (Winkel, 1997).

This thinking has consequence that the improvement of education to anticipate future needs and challenges need to be continuously done in order to be able to understand self, the environment and the decision-making process well and also to be steadier in preparing self in terms of knowledge, skills, attitudes and values, needed in career.

Conditions in UIN Imam Bonjol Padang indicated that most students have no maturity in the career choice direction because students are less thorough in understanding the majors entered and also the direction of career choices that will be pursued, some students are unsure of the direction of career choice after completing their education in MPI / BKI, some students do not like the MPI / BKI Department because this department is not appropriate with the desired, some students who feel afraid after completing education in the MPI / BKI department because the difficulty to get a job, some students in this department feel not recognized for their skill in guidance and counselingafter graduation and hard to work in school. This is revealed based on the results of observations and interviews of researchers with some students PPL less than 4 months, from September to December 2016. This problem arised because of various things of which are students do not know this MPI department concentration is the BKI that the career direction is to become a teacher because of the lack of information given when going into the department. Students do not get a clear direction from the campus about the MPI / BKI department. This study also gets the idea that most of the students, especially the students of MPI / BKI Department, do not have the maturity of the career choice direction because the fact that they meet in the field is not in appropriate with the expectation that they will work as management officer instead of being ateacher. This condition, among others, is the reason why students need to obtain guidance and counseling services in order to improve the maturity of career choice direction.

Educational institutions should be a comfortable and fun place for students to develop themselves and able to be a good first step in pursuingtheir career to the fore. The conditions described previously affirm that the need for the efforts of the campus to develop guidance and counseling service practices to provide understanding for thestudents in order to avoid some mistakes in understanding the majors entered.

Guidance and Counseling is a process of providing assistance performed by an expert to an individual using a variety of procedures, a method based on a counseling interview procedure in order for a person to be able to independently solve the problem so that the problems faced by the individual are completely solved (Prayitno and Amti 1994). Based on these considerations, then one of the ways that developed to change the views of students towards the MPI / BKI department is by providing a group guidance services. Group guidance is a group-provided service to students and collectively addresses appropriate topics within the group to improve the maturity of student's career choice direction.

Group guidance is the process of providing assistance to individuals through a group atmosphere that allows group members to actively participate and share experiences, insights, attitudes, or necessary skills to prevent problems or develop personality (Rusmana, 2009). The specific purpose of group guidance is to develop feelings, thoughts, perceptions, insights, and attitudes that support the realization of more effective behaviors (Prayitno, 2004). Group guidance activities can improve the maturity of student's career choices. Students who had been thinking in the MPI/ BKI department were not pleasant and difficult to get a job and so on, it will be changed through group guidance. The process of improving the maturity of a student's career choice of the chosen majors requires a change by using cognitive and emotional elements and can be done with several approaches and techniques.

The maturity of the career choice will be more effective in the appropriate ways and techniques, one of them is by using the modification of group guidance with the counseling models, one of the counseling approaches is modelling. Modelling aims to improve and change the behavior so that students are able in improving the maturity of career choices with a good direction. The factors of mastery experiences can improve the maturity of the career choice by using peer modelling way that can convince the individual that if someone else can, then he/ she can also (Pajares, 2005). 
Modelling can be one of the techniques / ways to induce a change strategy that is sourced from performance experience in the form of imitating an accomplished model. Another source is by inducing the source of the vicarious experience of live modelling in the form of observation of the real model (Alwisol, 2009).

\section{Method}

The type of this research is quantitative with Quasi Eksperiment approach of The Non Equivalent Control Group. The subjects of the study are UIN Imam Bonjol Padang students, consisting of 7 controls and 7 experimental groups who are identified as having very high, high, medium, low, and very low career choice direction taken from pretest processing. Research instrument using attitude scale maturity of career choice that meets the validity and reliability requirements of the research instrument. Then the data were analyzed using Wilcoxon Signed Rank Test and Kolmogorov Smirnov 2 Independent Samples by using Statistical Product and Service Solution (SPSS) program version 20.00..

\section{Results and Discussion}

The research data are obtained from members of the experimental and control group with 14 members. The implementation of group guidance activities in the experimental and control group was conducted from July 3, until August 232017, 8 times group guidance activities plus 4 assessment actions (Pretest and Posttest).

\section{Pretest and posttest result of experimental group}

Tabel 1. The difference of pretest and posttest of experimental group

\begin{tabular}{|c|c|c|c|c|c|c|c|}
\hline \multirow{2}{*}{ No } & \multirow{2}{*}{ code } & \multicolumn{3}{|c|}{ Pretest } & \multicolumn{3}{|c|}{ Posttest } \\
\hline & & score & $\%$ & Category & score & $\%$ & Category \\
\hline 1 & UF & 159 & 14.2 & ST & 170 & \multirow{4}{*}{57.1} & ST \\
\hline 2 & $\mathrm{AH}$ & 147 & 14.2 & $\mathrm{~T}$ & 168 & & ST \\
\hline 3 & ML & 119 & 14.2 & $\mathrm{~S}$ & 166 & & ST \\
\hline 4 & TA & 90 & \multirow[t]{2}{*}{28.7} & $\mathrm{R}$ & 166 & & ST \\
\hline 5 & $\mathrm{AP}$ & 91 & & $\mathrm{R}$ & 147 & \multirow{3}{*}{42.9} & $\mathrm{~T}$ \\
\hline 6 & YR & 62 & \multirow{2}{*}{28.7} & SR & 144 & & $\mathrm{~T}$ \\
\hline 7 & IM & 63 & & SR & 146 & & $\mathrm{~T}$ \\
\hline \multicolumn{2}{|r|}{ score } & 731 & \multirow[t]{2}{*}{100} & \multirow[t]{2}{*}{$\mathbf{R}$} & 1107 & \multirow{2}{*}{100} & \multirow[t]{2}{*}{ ST } \\
\hline & Mean & 104 & & & 158 & & \\
\hline
\end{tabular}

Based on Table 1, it is seen that overall there is an increase after being given group guidance services with modelling. The pretest result of the mean overall experiment group is 104 and increased in the posttest to 158 with an average increase of 54 and the increasing score between pretest and posttest is 376 . In addition, the categorization rate of maturity in the direction of career choice increased from the low category into a very high category. In the posttest results obtained four members of the group already has very high maturity direction of career choice and three others are still in the high category. Thus, group counseling service with modelling is effective in improving the maturity of student's career choice direction.

\section{Pretest and posttest result of control group}

Based on the data that the researcher obtained, it can be described that the result of the research before the treatment of group guidance and after given the treatment of group guidance both in the control group and experiment.Here described in detail about pretest and posttest result of control group. 
Tabel 2. The difference of pretest and posttest of control group

\begin{tabular}{|c|c|c|c|c|c|c|c|}
\hline \multirow{2}{*}{ No } & \multirow{2}{*}{ Code } & \multicolumn{3}{|c|}{ Pretest } & \multicolumn{3}{|c|}{ Posttest } \\
\hline & & Score & $\%$ & Category & score & $\%$ & Category \\
\hline 2 & $\mathrm{ME}$ & 147 & 14.2 & $\mathrm{~T}$ & 146 & \multirow{3}{*}{71.6} & $\mathrm{~T}$ \\
\hline 4 & AM & 90 & \multirow[b]{2}{*}{28.7} & $\mathrm{R}$ & 146 & & $\mathrm{~T}$ \\
\hline 5 & RA & 91 & & $\mathrm{R}$ & 142 & & $\mathrm{~T}$ \\
\hline \multicolumn{2}{|c|}{ Score } & 731 & \multirow[t]{2}{*}{100} & \multirow[t]{2}{*}{$\mathbf{R}$} & 1000 & \multirow{2}{*}{100} & \multirow[t]{2}{*}{$\mathbf{T}$} \\
\hline & & 104 & & & 142 & & \\
\hline
\end{tabular}

Based on Table 2, it can be seen that overall there is an increase of maturity scores in the direction of career choice of control group students after being given group guidance service without modelling. From the maturity level of student career choice is very low and low, after being given guidance service group without modelling rise to high. The overall average shows an increase from 104 to 142 with an average increase of 38 and the total score increased between the pretest and the posttest score is from 731 to 1000 with a score difference of 269 , and on the posttest result obtained one group member already hasvery high maturity in career choicedirection, five people in high category and one other person still in medium category. This means that there is an increase in the maturity of career choice direction in the control group given group counseling services without modelling.Tabel 3. Recapitulation of Pretest and Posttest Results of Experimental and Control Group

\begin{tabular}{|c|c|c|c|c|c|c|c|}
\hline \multicolumn{3}{|c|}{ Experimental } & \multicolumn{5}{c|}{ Control } \\
\hline Code & Pre & Post & Difference & code & Pre & Post & Difference \\
\hline UF & 159 & 170 & 19 & KLL & 159 & 160 & 1 \\
\hline AH & 147 & 168 & 21 & ME & 147 & 146 & 1 \\
\hline ML & 119 & 166 & 47 & FR & 119 & 143 & 24 \\
\hline TA & 90 & 166 & 76 & AM & 90 & 146 & 56 \\
\hline AP & 91 & 147 & 56 & RA & 91 & 142 & 51 \\
\hline YR & 62 & 144 & 82 & GR & 62 & 145 & 83 \\
\hline IM & 63 & 146 & 83 & CA & 63 & 118 & 55 \\
\hline Score & $\mathbf{7 3 1}$ & $\mathbf{1 1 0 7}$ & $\mathbf{3 7 6}$ & score & $\mathbf{7 3 1}$ & $\mathbf{1 0 0}$ & $\mathbf{2 6 9}$ \\
\hline Mean & $\mathbf{1 0 4}$ & $\mathbf{1 5 8}$ & $\mathbf{5 4}$ & Mean & $\mathbf{1 0 4}$ & $\mathbf{1 4 2}$ & $\mathbf{3 8}$ \\
\hline
\end{tabular}

According to Table 3, the average pretest of the experimental group of 104 is in the low category, and the posttest of 158 rises to very high while the difference between the pretest and posttest score is 376 . In the pretest the control group obtained the mean score is 104 thatis in the low category and the posttest result of 142 and is in the high category while the difference between pretest and posttest score is 269 . This means that the experimental group and the control group have improved score on the maturity of the career choice direction, but the improvement of maturity of the experimental group's career choice direction with group guidance service using modelling greater than the control group with group guidance services without using modelling. 


\section{HYPOTHESIS TESTING}

Before the treatment is given, the experimental group and control group scores should be equal and there are no statistically different scores, to prove that the variance of both groups is equal or equal, the Kolmogorov Smirnov 2 Independent Sample is used. Based on the analysis results it can be seen the value of Aymp. Sig. (2-tailed) / significances for the two-tailed test is 1,000 which with another form of 1,000> 0.05 . This means that there is no significant difference in the maturity of the career choice of the students in the experimental group and the control group before treatment is given, it can be concluded that the maturity of the students' career choice direction in the experimental group and the control group is equal.

\section{Test Result of Pretest and Posttest of ExperimentGroup}

The first hypothesis proposed in this study is "There is a difference in average score of maturity career choice direction of experimental group students before and after follow group guidance activities with modelling". Hypothesis testing is done by statistical analysis techniques Wilcoxon Signed Ranks Test through SPSS computer program version 20.00. Based on the analysis, it is obtained that the probability number Asymp. Sig. (2-tailed) maturity of student's career choice directionis 0.001 or probability below alpha $(0.001<0.05)$. Based on these results, H0 is rejected and HI is accepted. Thus, the first hypothesis tested in this study is accepted, ie "There is a difference of maturity of the career choice direction of students in the experimental group before and after the treatment of group guidance services with modelling".

Furthermore, from the results of the analysis also obtained 7 students involved in the calculation has improved in the maturation of career choice direction before and after treatment. Based on the results of hypothesis testing, it can be interpreted the maturity of career choice of students improved after getting treatment group guidance with the modelling. Mean rank or average increase is 4.00 , while the number of negative rank or sum of ranks is 28.00 . Ties is the same pretest and posttest values that is 0 , it means that there is no equal value between pretest and posttest. So it can be concluded that 7 students of experimental group improved in the maturity score of career choice direction.

\section{Test Results of Pretest and Posttest Control Groups}

The second hypothesis of this study is also tested using statistical analysis with Wilcoxon Signed Ranks Test technique with SPSS version 20.00. The second hypothesis tested in this study is "There is a difference in average score of maturity of career choice direction of control group students before and after following group guidance without modelling". The analysis results obtainedAsym. Sig. (2-tailed) value is 0.017 less than 0.05 , it can be concluded that "H0 is rejected and $\mathrm{H} 1$ is accepted". This means that there is a difference between the maturity of the student's career choice direction for the pretest and posttest of the control group after following the group guidance without modelling. Thus, the second hypothesis tested in this study is accepted stating that "There is a difference in the maturity of career choice direction of control group students, before and after the treatment of group counseling services by modelling ".

Based on the result of the analysis, it is known that the value of $7^{\mathrm{a}}$ in the positive ranks means that 7 students of the control class improve in the maturity score of career choice direction from pretestto posttest. The occurrence of the improvement because given the group guidance service without modelling. Mean rank or average increase is 4.00 and the number of negative rank or sum of ranks is 28.00 . In addition, Ties is the same pretest and posttest value that is 0 , it means that there is no group member has the same pretest and posttest results.

\section{The Result of Posttest of Experiment and Control Group}

Testing of this third hypothesis uses Kolmogorov Smirnov 2 Independent test techniques. The third hypothesis tested is "There is a difference of maturity in the career choice direction of the experimental group which is given the group guidance service with the modelling, with the control group students who are given the group guidance service without modelling (ordinary group guidance)". Based on these techniques, the test results of Kolmogorov Smirnov 2 Independent test on posttest analysis can be seen that the maturity of student's career choice direction in Asymp column. Sig. (2-tailed) for the two-tailed test is 0.012 with another form $(0.012<0.05)$. Then H0 is rejected and H1 is accepted, it means, "there is a significant difference in the maturity of the career choice direction of the experimental group students following the group guidance service by modelling with the control group students following the group guidance service without modelling.

Then, a normalized genn scores or NGS (g) test is conducted to see the effectiveness of the experimental group and the control group, based on NGS (g) result, the NGS (g) of experimental group is 
0.76 with high qualification and NGS (g) of control group is 0.54 with medium qualification. Thus, it can be illustrated that overall average the maturity of students' career choice direction improve after service, but group guidance with modelling is more effective in improving the maturity of the career choicedirection compared to the control group.

Based on the above description, it also can answer the hypothesis of this study which reads that " group guidance service with modelling is more effective in changing the maturity of student' career choice direction". The increase in the experimental group score is higher than in the control group.

\section{DISCUSSION}

\section{Experimental Group Before and After Given Group Guidance Services with Modelling.}

The results prove that group guidance with modelling is effective in improving the maturity of student's career choice direction. All members of the group experienced an increase in the maturity score of students' career choice direction from low category to very high.

The implementation of group counseling services with modelling aims to improve the maturity of student's career choice direction. Group guidance is a series of activities that provide experience to students in interacting with each other within the scope of the group, solving a common problem, exchanging thoughts, thereby altering the perceptions, views, and maturity of student's career choice direction/ topic being discussed (Wingkel. 2004). Through the group guidance, students can gain a new understanding of the model, so that it can change the maturity of career choice direction. after the students are given group counseling services with modelling, posttest score increases. The acquisition of maturity scores ofcareer choice direction of experimental group increase from low to very high category. Difference in mean value score of maturity career choice direction before and after given treatment is high enough. Difference in the achievement score of the maturity of the career choice direction is the result of being given group counseling services with modelling.

Based on the research results, it can be summarized that the modelling approach can be one effective strategy in the guidance of the group, as an effort to improve the maturity of student career choices direction. With the attention stage is the students with full attention and passion to pay attention to the model in delivery the material, retention is the students imagine and recall the material that has been submitted to the model and directly ask about what is not understood. Production is the students in the group begin to digest what is properto beimitated and not proper to be imitated according to their own circumstances and decide the choice, one of them by revealing what is should be and should not be done. The motivation is the motivation to the various thoughts, feelings, choices and actions or efforts made by the model who already succeeded in his/ her career presented in the form of discussion of various topics, by expressing directly if I could and this motivation also come from the model in order to reinforce what has become a strength for group members.

\section{Differences in Maturity of Student's Career ChoiceDirectionof Control Group Before and After given Group Guidance Services without Modelling.}

Based on the data analysis, it is known that in the control group there are differences in the maturity of student's career choice direction before being given group counseling service (without modelling) with the maturity of student's career choice directionafter being given group guidance service (without modelling). Based on the preliminary score, the maturity of the students' career choice directionof control group is in the low category. After being given treatment in the form of group guidance services without modelling, then there is an increase in the score of maturity direction of student's career choice direction that is in high category. Difference in mean score value of the maturity of studentscareer choice direction before and after being given treatment is not so high than the experimental group. Although there are statistically significant differences and improvement in the maturity score of student's career choice direction in the control group, there are still one student in medium category, fivein high category and one in very high category.

At the initial meeting of group guidance activities without modelling, the students were silent and less volunteer in expressing their opinions. Responding to that, group leaders seek group dynamics by inviting students to talk about the topic being discussed. It aims to invite group members to dare to speak in front of his/ her friends.

Prayitno (2012) explains the purpose of group guidance is for group members to be able to speak in front of the public, so that with group guidance activities can bring out the courage of the individuals to speak. Through the group counseling service, disturbing things can be expressed, relaxed, lightened, through various means; a dead-end, stumped, or frozen mind is thawed and dictated through new inputs and responses.Distorted or narrow perceptions and insights are straightened and expanded through mind- 
blowing, awareness, and explanation.Thematurity of the student's career choice direction that is not objective, confined and uncontrollable, if necessary replaced with a new more effective.

Based on the opinions expressed above, it can be explained that group guidance activities allows students to acquire the necessary abilities in relationships with others and themselves. This can happen by generating intensive group dynamics and discussion of hot topics, encouraging and assisting students in developing feelings, thoughts, perceptions, insights, and maturity of student's career choice direction that support more effective and responsible behaviors . In addition, Sihotang, Yusuf and Daharnis (2013) explain that through conducted group guidance services many things can be discussed by the students in groups so that students have an objective understanding, able to think positively and willing to implement commitments that have been agreed to assist students in achievement early adolescent developmental tasks in the aspect of emotional independence.

Group guidance activities carried out in 5 stages: starting from the stage of formation, transition, activity, inference, and finishing. By procedure, the implementation of group counseling services with modelling is the same as regular group counseling, only at the stage of formation and activity, discussion of topics in the control group does not use special techniques such as modelling. At the stage of activity the task topic is discussed together with group members and group leaders become facilitators in the activity. However, in practice, group members have not been fully active in group activities, students are informed only through group leaders.

Based on the results of researcher's observation at the first meeting, group dynamics has not been prominent, the researcher interviewed several members of the control group in the process of group guidance activities aboutthe activeness of students talking in groups. The results of the interview obtained information that group members who lack opinions in the group guidance activities caused by several factors: fear of ridicule by other group members, not used to talking in front of the crowd, do not know what to say in the group, nervous, and lack of knowledge about the subject matter.

Putra and Daharnis (2013) revealed that group counseling services are also effective in improving student self efficacy. Group guidance is expected to be excellent among other services as it emphasizes the dynamic aspects of the group which have high spirit, smooth and steady cooperation, and mutual trust among its members.

Respondingto the results of the implementation of the activities at the first meeting, researchers conducted various evaluations about activitiesimplementation, ranging from techniques used, group dynamics and group members' constraints.

Membership is one of the key elements in the group life process. The role of the group will not be realized without the active participation of the group members, and even more than so. The role that group members should play as expected. Prayitno (2012) states that the role of group members in group counseling services is of, by and for the members themselves. Each member of the group is directlyactiveand independent, while the group leader is only the referee who manages the activities, the rules of the game, the peacemaker and the one who encourage the cooperation and togetherness atmosphere.

So it can be summarized that the maturity of student's career choice direction can be changed by using group guidance without modelling. However, the change is not very effective fromthe group guidance experimental using modelling, because in the group guidance activities, the group members only obtain new information and understanding from the group leader and the opinions of some group members who argue without direct and independent activities in the group.

\section{Differences in Maturity of Student's Career Choice Direction of Experiment Group and Control Group.}

Implementation of research aims to determine the effectiveness of the implementation of group guidance services with modelling to improve the maturity of student's career choice direction in UIN Imam Bonjol Padang. The results showed that there is a different maturity of student's career choice direction in the experimental group given group guidance service with modelling with control group given group guidance service without modelling. The increase of maturity score of the student's career choice direction of experimental group is more than the control group given treatment in the form of group guidance service without modelling.

The modelling is an approach and technique in guidance and counseling that can effectively deal with problems related to the maturity of career choice direction. Therefore, the attempt to change the maturity of student's career choicedirection is effective done by using group guidance with modelling. Students are more active than ordinary group guidance, because in modelling students can see and listening the model directly.. The main objective of modelling focuses on assisting students in improving the maturity of career choice directions. 
The model presented in group guidance activities is able to motivate group members who have low maturity of career choice direction. This is because the model presented is taken from alumnus who come from the same majors who have succeeded in their respective fields in his career. In addition, the model and other group members are also in the same environment at UIN Imam Bonjol Padang, so group members can easily observe the model not only during group guidance activities but also outside of group activities. This is as revealed by Bandura (2009: 3) that the model that has similarities with the observer has a stronger effect in influencing the maturity of one's career choice direction.

As an inner belief, the maturity of the career choice direction can be realized in the form of thoughts, feelings, choices and motivations, so that with group guidance activities, group members can reflect on different thoughts, feelings, choices and motivations on various topics who are raised in group guidance. As Prayitno (2004: 2) reveals that group guidance can be a good place to reflect feelings, thoughts and add insights that can lead to an objective maturity of student's career choice direction.

The existence of the model makes the group atmosphere very dynamic. This is because in discussing the topic of group guidance activities there are different thoughts, feelings, choices and motivations between group members who have low maturity of career choice direction and models that have a high maturity of career choice direction. This situation is in line with what Bandura (2009: 5) and Gredler (2009: 365) suggest that the maturity of career choice direction has an effect on human behavior through various processes, namely cognitive, affective, motivational and selection.

Group guidance with modelling makes learning become easier in order to improve the maturity of student's career choice direction. With modelling, the stages of activities within the group guidance become more effective and efficient. This is very different from the usual group guidance that uses more discussion methods.Group guidance with modelling, the process of attention become a container or very good activity place. This is because the guidance of the group is able to accommodate all expression in the form of thoughts, feelings, maturity of student's career choice direction and insight from all members of the group. With group readiness, the model is able to present all of his/ her thoughts, feelings, choices and motivations without hesitation and shame. Similar to group members, comfortable and quiet group conditions make it easy for them to give attention to the best. By observing the model's thoughts, feelings, choices and motivations in improving the maturity of the career choice direction, group members can represent something and what is appropriate with each of them. The second, third and fourth stages of the modelling process are representation, production and motivation,further easily accomplished. With good attention from all members of the group, then as a series of activities, then by considering the model, students are able to choose thoughts, feelings, choices and motivations along with actions that may be suitable to have and try. Thus each member of the group can acquire the thoughts, feelings, maturity of the student's career choice direction and actions derived from the models that they may be able to do in improving the maturity of the career choice direction according to the topics covered. In this way, students do not take long time to get formulas in the form of thoughts, feelings, choices and motivations that they may get after going through long processes through experience

\section{References}

Afdal. 2015. "Model Bimbingan Karir Kolaboratif dalam Memantapkan Perencanaan Karir Siswa SMA". Disertasi tidak diterbitkan. Bandung: Universitas Pendidikan Indonesia.

Ahmadi, A. 2013. Sosiologi Pendidikan, Jakarta: Rineka Cipta.

Alwisol. 2009. Psikologi Kepribadian. Malang: UMM Press.

Aminudin, D. dan Solihatun 2014. "Efektifitas Teknik Modelling dalam Meningkatkan Efikasi Diri Siswa dalam Menghadapi Ujian. Tesis tidak diterbitkan. Padang: PPs BK UNP.

Anggara, F. 2016. "Efektifitas Layanan Bimbingan kelompok dengan Modelling dalam Meningkatkan Efikasi Diri”. Tesis tidak diterbitkan. Jakarta: Universitas Indraprasta.

Arikunto, S. 2010. ProsedurPenelitian: Suatu Penedekatan Praktik. Jakarta: Rineka Cipta.

Feist, J., Gregory J. 2008. Teori Kepribadian. Theories of personality. Jakarta: Salemba Humanika.

Gibson, R. L. dan Marianne, H., Mitchell. 1995. Introduction to Counseling and Guidance. New Jersey: Prentice-Hall. 
Gladding, S. T. 1994. Effective Group Counseling. Greensboro: ERIC counseling and student service clearing house.

Handoko, T.H. 1996. Manajemen Personalia dan Sumber Daya Manusia. Yogyakarta: BPFE

Herr. E. L. dan Cramer. 1979. Career Guidence And Counseling Througth The Life Span. Bouston: Browmn and Company.

Hurlock, B., E. 2002. Child Development Sixh Edition. Terjemahan. Med meitasari Tjandrasa. Jakarta: Erlangga.

Hurlock, E. B. 1980. Psikologi Perkembangan. Suatu pendekatan sepanjang rentang kehidupan. Jakarta: Erlangga.

Irianto, A. 2010. Statistik: Konsep dasar, aplikasi dan pengembangannya. Jakarta: Kencana.

Isaacson, L. E. 1986. Career Information in Counseling and Career Development ( $4^{\text {th }}$ Edition). Boston London Sydney Toronto: Allyn dan Bacon, Inc.

Mappiare, A. 2006. Kamus Istilah Konseling dan Terapi. Jakarta: Raja Grafindo Persada.

Nandang, R. 2009. Bimbingan dan Konseling Kelompok di Sekolah (Metode, Tekhnik dan Aplikasi). Bandung. Rizki Press.

Pajares, F. 2005. Self Efficacy During Childhood and Adolescence. Information Age Publishing All Rights of Reproduction in Any Form Reserved.

Prayitno dan Amti, E. 2004. Dasar-dasar Bimbingan dan Konseling. Jakarta: Rineka Cipta.

Prayitno dkk. 1997. Seri Pemandu Pelaksanaan Bimbingan dan Konseling di SLTP. Jakarta: Ikrar Mandiri Abadi.

Prayitno, dkk. 1997. Seri Pemandu Pelaksanaan Bimbingan dan Konseling di Sekolah. Buku III. Pelayanan Bimbingan dan Konseling di Sekolah Menengah (SMA). Jakarta: Ikrar Mandiri Abadi.

Prayitno. 1995. Layanan Bimbingan dan Konseling Kelompok (Dasar dan Profil). Jakarta. Ghalia indonesia.

Prayitno. 2005. Layanan Bimbingan dan Konseling Kelompok. Jakarta: Ghalia Indonesia.

Prayitno. 2012. Seri Panduan Layanan dan Kegiatan Pendukung Konseling. Program Pendidikan Profesi Konselor Universitas Negeri Padang.

Program Pascasarjana UNP. 2014. Buku Panduan Penulisan Tesis dan Disertasi. Padang: UNP.

Putra, S. A., dan Daharnis (2013). Efektifitas Layanan Bimbingan Kelompok dalam Meningkatkan Self Efiikasi Siswa. Jurnal Ilmiah Konseling, (Online), Vol2: 1-6 (diakses 8 maret 2017)

Rakhmat, Jalaluddin. 2009. Psikologi Komunikasi. Bandung: Remaja Rosdakarya.

Riduwan dan Sunarto. 2002. Pengantar Statistika. Bandung: Alfabeta.

Riduwan dan Sunarto. 2009. Pengantar Statistik untuk Penelitian: Pendidikan, sosial, komunikasi, ekonomi, dan bisnis. Bandung: Alfabeta.

Rusmana, N. 2009. Bimbingan dan Konseling Kelompok di Sekolah. (Metode, Teknik Aplikasi). Bandung: Rizki Press.

Sarwono, S., W. 2002. Pengantar Psikologi Umum. Jakarta: Raja Grafindo. 
Schulze, P. dan Jhon M. Schulze. 2003. "Believing is Achieving: The Implications of Self-Efficacy", Research for family and Consumer Sciences Education.

Setiyowati, Eny. 2015. Hubungan Efektivitas Bimbingan Karir dan Orientasi Masa Depan dengan Keputusan Karir Remaja. (online) (http://eprints.ums.ac.id/33847/7/FULLTEXT.pdf). Diakses 6 April 2016.

Setoyati, P. 2015. Metode Penelitian Pendidikan dan Pengembangan, Jakarta: Kencana.

Sharf. R.S 1992. Applying Career Development Theory to Counseling. Clifornia: Brooks/Cole Publishing Company.

Shertzer dan Stone. 1980. Fundamentals of Counseling. Geneva: Houghton Mifflin Company Boston.

Sihontang, N., Yusuf, A. M., dan Daharnis. 2013. Pengaruh Layanan Bimbingan Kelompok Terhadap Pencapaian tugas Perkembangan Remaja Awal dalam Aspek Kemandirian Emosional ( Studi Eksperimen di SMp Frater Padang) Jurnal Ilmiah Konseling, (Online), Vol 2(4)

Sugiyono. 2010. Metode Penelitian Pendidikan Pendekatan Kuantitatif, Kualitataif, dan RdanD. Bandung. PT. Alfabeta.

Sukardi, Ketut D. 2007. Bimbingan Karier di Sekolah-sekolah. Jakarta: Ghalia

Suranata, K. 2009. "Hubungan Antara Kesesuaian Tipe Kepribadian dan Model Lingkungan dengan Kematangan Arah Pilihan Karier". Tesis tidak diterbitkan. Padang: PPs UNP.

Syamsi, I. 2000. Pengambilan Keputusan dan Sistem Informasi. Jakarta: Sinar Grafika Offset

Undang-undang Nomor 20 tahun 2003 tentang Sistem Pendidikan Nasional. Jakarta: Kementrian Pendidikan Nasional.

Uno, H. B. 2005. Orientasi Baru dalam Psikologi Pembelajaran. Jakarta: Bumi Aksara.

Uno, H. B. 2010. Kiat Sukses dalam Karier. Bogor: Ghalia Indonesia.

Warters, J. 1960. Group Guidance Principles and Practices. New York: McGraw-Hill Book Company.

Winkel, W. S., dkk. 1997. Bimbingan dan Konseling di Institusi Pendidikan. Yogyakarta: Media Abadi.

Winkel, W.S. 2005. Bimbingan dan Konseling di Institusi Pendidikan. Edisi Revisi. Jakarta: Gramedia

Winkel. W.S, dan Hastuti, S. 2004. Bimbingan Karir di Institusi Pendidikan. Jakarta: Media Abadi

Yusuf, A. M. 2005. Kiat Sukses dalam Karir. Bogor. Ghalia Indonesia.

Zunker, V. G. 1986. Career Counseling:Applied Concepts Of Life Planning. Second Edition Chapter 2: Theories Of

Career Development. Monterey, California: Brooks/Cole Publishing Company. 